Journal of Current and Advance Medical Research

January 2017, Vol. 4, No. 1, pp. 17-22

http://www.banglajol.info/index.php/JCAMR

ISSN (Print) 2313-447X

ORIGINAL ARTICLE

OPEN@ACCESS

\title{
Knowledge of Snake Bite Management among Health Service Providers at a Rural Community of Bangladesh
}

\author{
HM Nazmul Ahsan ${ }^{1}$, Md. Ridwanur Rahman², Robed Amin², Enamul Hoque Chowdhury ${ }^{4}$
}

\begin{abstract}
${ }^{1}$ Assistant Professor, Department of Medicine, Shaheed Suhrawardy Medical College, Dhaka, Bangladesh; ${ }^{2}$ Professor \& Head, Department of Medicine, Shaheed Suhrawardy Medical College, Dhaka, Bangladesh; ${ }^{3}$ Associate Professor, Department of Medicine, Dhaka Medical College, Dhaka, Bangladesh; ${ }^{4} \mathrm{MA}$ in Economics, Statistician \& Research Expert, Dhaka, Bangladesh
\end{abstract}

[Reviewed: 30 January 2016; Accepted on: 1 March 2016; Published on: 1 January 2017]

\section{Abstract}

Background: Snake bile is a very common incidence among the rural people. Objective: This study was aimed to assess the pattern of snakebite in rural community through community engagement. Methodology: It uses the methodological triangulation qualitative and quantitative approach as well as a case study design in analyzing data, whereby the exploratory-descriptive design is followed. The findings from survey study on snake bite have been elicited from face to face interview with 243 number of medical professionals/health service providers consisting of 113 number of MBBS doctors, 86 number of nurses and 46 number of other health practitioners. The study area consisted of 5 zilla sadar hospitals and 15 upazilla health complexes. We purposively select the 243 sample(Doctors, Nurses, Paramedics ,Others) from the selected districts and its consisting random upazillas from the govt. sector hospitals keeping in mind gender balance (Male -Female) as a primary total target population. So in total, 5division and itsconsisting random upazilas hospital including union health complex hospital personnel will be interviewed throughout mention areas of Bangladesh. Result: Most of the health professionals (93.8\%) stated that the existence of facilities in their respective hospitals is not adequate to manage the treatment of snake bite victims. Of the total number of medical personnel - around $30.0 \%$ of the health professionals had the opportunity to manage snake bite in their respective span of service (50.4\% of MBBS docs + $11.6 \%$ of nurses $+11.4 \%$ of other practitioners).The findings show that majority of $87.6 \%$ of doctors, $85.0 \%$ of nurses and $95.5 \%$ of other practitioners mentioned rainy season as the most prevalent time for occurrence of snake bite in rural areas of Bangladesh. As for whether all snake bites are poisonous- around $17.0 \%$ of doctors followed by $18.6 \%$ of nurses and $16.0 \%$ of other practitioners are found to have wrong notion about mentioning that all snake bites are poisonous but in reality this is not true. Conclusion: There is insufficient knowledge, skill and experience of how to treat snake bite victims. [Journal of Current and Advance Medical Research 2017;4(1):17-22]

Keywords: Snake bile; rural community; management

Correspondence: Dr. H.M Nazmul Ahsan, Assistant Professor, Department of Medicine, Shaheed Suhrawardy Medical College, Dhaka, Bangladesh; Email:

Cite this article as: Ahsan HMN, Rahman MR, Amin R, Chowdhury EH. Status of Snake Bite at a Rural Community of Bangladesh: A Survey. Journal of Current and Advance Medical Research 2017;4(1):17-22

Conflict of Interest: All the authors have declared that there was no conflict of interest.

Funding: This research project was not funded by any group or any institute on.

Contributions to authors: HMNA, MRR, RA \& EHC have contributed in protocol preparation up to surgical procedures as well as the report writing; furthermore, HMNA \& MRR have written the manuscript and have revised the manuscript.

Copyright: (O2017 Ahsan et al. Published by Journal of Current and Advance Medical Research. This article is published under the Creative Commons CC BY-NC License (https://creativecommons.org/licenses/by-nc/4.0/). This license permits use, distribution and reproduction in any medium, provided the original work is properly cited, and is not used for commercial purposes. 


\section{Introduction}

Snake bite is a result of an unfortunate accidental interaction between a snake and a human victim ${ }^{1}$. It is the single most important toxin-related injury, causing substantial mortality in many parts of the Africa, Asia, and the Americas. Snake bite is a burning public health issue in Bangladesh as a disaster prone country and its geographical position and climatic conditions ${ }^{2}$. Snake bite, particularly in the rural Bangladesh is a major cause of mortality and morbidity, and it has a significant impact on human health and economy through treatment related expenditure and loss of productivity ${ }^{3}$. Most often the victim of snake bite is a poor, young and active individual.

Biting occurs mostly when individuals are at work, engaging in activities such as cultivation, fishing, plantation, wood collection, or tending crops or gardens. Among snake bites $30 \quad(60 \%)$ were venomous and $20(40 \%)$ snake bite cases were nonvenomous. The common victims were farmers (53\%) and housewives (13\%). The bites were commonly encountered during rural foot walking (32\%) followed by sleeping (15\%). 55\% were bitten during outdoor and agriculture related activities. $65 \%$ had sustained bite in lower limbs ${ }^{4}$. The majority $(82 \%)$ of the snakebites were observed during the rainy season. Total $98 \%$ patients applied multiple tight tourniquets in the affected $\operatorname{limb}^{5}$. A common local practice (seen in $85 \%$ ) was to receive pre hospital treatment from 'Ohzas'.

In the absence of any epidemiological survey data, there was a dearth of information about snake bite from Bangladesh. During 1988-89, a small survey was conducted in 50 Upazillas (sub-districts) of Bangladesh recorded 764 occurrences of snake bite, of which 168 (22\%) died and a postal survey conducted in 21 of the 65 administrative districts in 1995-1996 estimated an annual incidence of 4.3 per 100,000 populations and a case fatality of $20 \%^{3}$. In this study, Chittagong Division and Barisal Division had the highest annual incidence of snake bites $^{6}$. These estimates were based on data from small studies and due to methodological limitations; the estimates were unlikely to be representative of the whole country population. Treatment of snake bite was largely dominated by traditional snake charmers (Ozha). People used to be content with their traditional methods of tight tourniquet, multiple incisions at bite site, application of herbal products and different rituals. It was felt that the skill and knowledge of management has to be transmitted amongst the general physicians attending the victims at the primary level of health care. This study was undertaken to assess the pattern of snakebite in rural community through community engagement.

\section{Methodology}

It uses the methodological triangulation qualitative and quantitative approach as well as a case study design in analyzing data, whereby the exploratorydescriptive design is followed. The findings from survey study on snake bite have been elicited from face to face interview with 243 number of medical professionals/health service providers consisting of 113 number of MBBS doctors, 86 number of nurses and 46 number of other health practitioners. The study area consisted of 5 zilla sadar hospitals and 15 upazilla health complexes. We purposively select the 243 sample (Doctors, Nurses, Paramedics, Others) from the selected districts and its consisting random upazillas from the govt. sector hospitals keeping in mind gender balance (Male Female) as a primary total target population. So in total, 5division and its consisting random upazilas hospital including union health complex hospital personnel (From District, Upazilla \& Community Hospitals) will be interviewed throughout mention areas of Bangladesh. It uses the methodological triangulation qualitative and quantitative approach as well as a case study design in analyzing data, whereby the exploratory-descriptive design is followed. This study carry out to see the common type of snakes in local area with clinical presentations, complications and outcome of snake bite patients in service. Firstly, all eight administrative divisions were selected. Afterwards, one districts and upazila from each selected division are randomly selected and also focus to be given in the Community clinic is the lowest administrative unit in both Urban and rural areas in Bangladesh. After obtaining the respondent's written consent, information was collected on snake bites and their consequences, and treatment seeking behavior following snake bites from the respondents. The respondents answered for every member who spent any part of the past year in the selected hospital. All information were collected using an interviewer administered pre-tested partially close ended questionnaire through face to face interview. Frequency of snake bite(s) on each member and their length of management in months in that hospital during past 12 months were collected from the respondents. Later on, person-time was converted from person-month to person-years to calculate annual incidence density of snake bites in rural Bangladesh. 


\section{Result}

The findings from survey study on snake bite have been elicited from face to face interview with 243 number of medical professionals/health service providers consisting of 113 number of MBBS doctors, 86 number of nurses and 46 number of other health practitioners. The study area consisted of 5 zilla sadar hospitals and 15 upazilla health complexes. The field/survey findings are illustrated under the following tables.
Most of the health professionals (93.8\%) stated that the existence of facilities in their respective hospitals is not adequate to manage the treatment of snake bite victims. Of the total number of medical personnel - around $30.0 \%$ of the health professionals had the opportunity to manage snake bite in their respective span of service $(50.4 \%$ of MBBS docs $+11.6 \%$ of nurses $+11.4 \%$ of other practitioners). Of the total 243 health professionals only $17.3 \%$ had scope to manage snake bite victim/case last one year and only $13.2 \%$ of them had experienced in the management of nocturnal snake bite case.

Table 1: Receipt of Training and Need for Management on Snake Bite

\begin{tabular}{|c|c|c|c|c|c|c|c|c|}
\hline \multirow{3}{*}{$\begin{array}{l}\text { Receipt of training } \\
\text { and management on } \\
\text { snake bite }\end{array}$} & \multicolumn{8}{|c|}{ Type of Health Service Providers } \\
\hline & \multicolumn{2}{|c|}{ Doctor $(n=113)$} & \multicolumn{2}{|c|}{ Nurse $(n=86)$} & \multicolumn{2}{|c|}{ Others $(n=44)$} & \multicolumn{2}{|c|}{ Total $(n=243)$} \\
\hline & Yes & No & Yes & No & Yes & No & Yes & No \\
\hline $\begin{array}{l}\text { Receipt status of } \\
\text { training on snake } \\
\text { bite }\end{array}$ & $15.0 \%$ & $85.0 \%$ & $8.1 \%$ & $91.9 \%$ & $15.9 \%$ & $84.1 \%$ & $12.8 \%$ & $87.2 \%$ \\
\hline $\begin{array}{l}\text { Need for training on } \\
\text { snake bite } \\
\text { management }\end{array}$ & $85.0 \%$ & $7.0 \%$ & $90.7 \%$ & $3.3 \%$ & $90.9 \%$ & $1.6 \%$ & $88.1 \%$ & $11.9 \%$ \\
\hline $\begin{array}{l}\text { Existence of } \\
\text { adequate facilities in } \\
\text { hospital for snake } \\
\text { bite management }\end{array}$ & $8.8 \%$ & $91.2 \%$ & $5.8 \%$ & $94.2 \%$ & $.0 \%$ & $100.0 \%$ & $6.2 \%$ & $93.8 \%$ \\
\hline $\begin{array}{l}\text { Management any } \\
\text { snake bite case yet }\end{array}$ & $50.4 \%$ & $49.6 \%$ & $11.6 \%$ & $88.4 \%$ & $11.4 \%$ & $88.6 \%$ & $29.6 \%$ & $70.4 \%$ \\
\hline $\begin{array}{l}\text { Management of any } \\
\text { snake bite last one } \\
\text { year }\end{array}$ & $30.1 \%$ & $69.9 \%$ & $3.5 \%$ & $96.5 \%$ & $11.4 \%$ & $88.6 \%$ & $17.3 \%$ & $82.7 \%$ \\
\hline $\begin{array}{l}\text { Any experience on } \\
\text { management of } \\
\text { nocturnal snake bite } \\
\text { case }\end{array}$ & $21.2 \%$ & $78.8 \%$ & $5.8 \%$ & $94.2 \%$ & $6.8 \%$ & $93.2 \%$ & $13.2 \%$ & $86.8 \%$ \\
\hline
\end{tabular}

Of the 72 health professionals who experienced management of snake bite case, only $55.6 \%$ of them had managed snake bite victim/case last one year and $40.3 \%$ of them had experienced in the management of nocturnal snake bite case.

Table 2 shows the percentage of statement/ responses of medical/ health service providers with regard to their knowledge on signs and symptoms of poisonous/venomous snake-bite. It is observed that the doctors could indicate most of the signs and symptoms $(72.0 \%$ to $94.0 \%)$ of snake bite followed by the nurses who could indicate around $50 \%$ to $90 \%$ of the signs and symptoms of snake bite and other practitioners could indicate signs and symptoms of snake bite ranging from $54.0 \%$ to $89.0 \%$.

It is seemingly evident from the findings that the MBBS doctors are more knowledgeable about the signs and symptoms of snake bite victims than those of the knowledge level of nurses and other practitioners on signs and symptoms of snake bite. However findings show that health professionals are not aware of all of the signs and symptoms of snake bite. So, refreshers courses and practical learning lessons may be imparted to medical professionals to understand the signs and symptoms of snake bite both venomous and non-venomous easily and effectively. 
Table 2: Percentage of Health Service Providers' Knowledge on Signs and Symptoms of Poisonous Snake Bite

\begin{tabular}{|c|c|c|c|c|c|c|c|c|c|}
\hline \multirow{3}{*}{$\begin{array}{l}\text { Knowledge on signs } \\
\text { and symptoms of } \\
\text { poisonous snake bite }\end{array}$} & \multicolumn{9}{|c|}{ Type of health service providers } \\
\hline & \multicolumn{3}{|c|}{ Doctor $(n=113)$} & \multicolumn{3}{|c|}{ Nurse $(n=86)$} & \multicolumn{3}{|c|}{ Others $(n=44)$} \\
\hline & Yes & No & DK & Yes & No & DK & Yes & No & DK \\
\hline $\begin{array}{l}\text { Swelling with pain and } \\
\text { blistering }\end{array}$ & $92.9 \%$ & $6.2 \%$ & $.9 \%$ & $82.6 \%$ & $15.1 \%$ & $2.3 \%$ & $88.6 \%$ & $6.8 \%$ & $4.5 \%$ \\
\hline Dizziness and vomiting & $92.0 \%$ & $6.2 \%$ & $1.8 \%$ & $89.5 \%$ & $8.1 \%$ & $2.3 \%$ & $88.6 \%$ & $4.5 \%$ & $6.8 \%$ \\
\hline Blurring of vision & $92.0 \%$ & $6.2 \%$ & $1.8 \%$ & $90.7 \%$ & $7.0 \%$ & $2.3 \%$ & $84.1 \%$ & $9.1 \%$ & $6.8 \%$ \\
\hline Convulsion & $78.8 \%$ & $18.6 \%$ & $2.7 \%$ & $75.6 \%$ & $20.9 \%$ & $3.5 \%$ & $65.9 \%$ & $18.2 \%$ & $15.9 \%$ \\
\hline Unconsciousness & $85.0 \%$ & $10.6 \%$ & $4.4 \%$ & $89.5 \%$ & $9.3 \%$ & $1.2 \%$ & $72.7 \%$ & $11.4 \%$ & $15.9 \%$ \\
\hline Heaviness of eyelids & $85.0 \%$ & $6.2 \%$ & $8.8 \%$ & $76.7 \%$ & $7.0 \%$ & $16.3 \%$ & $72.7 \%$ & $2.3 \%$ & $25.0 \%$ \\
\hline $\begin{array}{l}\text { Weakness of neck } \\
\text { muscle }\end{array}$ & $81.4 \%$ & $7.1 \%$ & $11.5 \%$ & $73.3 \%$ & $11.6 \%$ & $15.1 \%$ & $68.2 \%$ & $2.3 \%$ & $29.5 \%$ \\
\hline Difficulty in swallowing & $74.3 \%$ & $13.3 \%$ & $12.4 \%$ & $64.0 \%$ & $18.6 \%$ & $17.4 \%$ & $61.4 \%$ & $9.1 \%$ & $29.5 \%$ \\
\hline $\begin{array}{l}\text { Nasal } \\
\text { regurgitation/voice }\end{array}$ & $72.6 \%$ & $15.0 \%$ & $12.4 \%$ & $59.3 \%$ & $23.3 \%$ & $17.4 \%$ & $61.4 \%$ & $6.8 \%$ & $31.8 \%$ \\
\hline Difficulty in respiration & $82.3 \%$ & $8.0 \%$ & $9.7 \%$ & $87.2 \%$ & $9.3 \%$ & $3.5 \%$ & $79.5 \%$ & $4.5 \%$ & $15.9 \%$ \\
\hline $\begin{array}{l}\text { Bleeding from gum and } \\
\text { vomiting }\end{array}$ & $66.4 \%$ & $19.5 \%$ & $14.2 \%$ & $55.8 \%$ & $26.7 \%$ & $17.4 \%$ & $54.5 \%$ & $15.9 \%$ & $29.5 \%$ \\
\hline $\begin{array}{l}\text { Persistent bleeding } \\
\text { from bite site }\end{array}$ & $80.5 \%$ & $14.2 \%$ & $5.3 \%$ & $82.6 \%$ & $8.1 \%$ & $9.3 \%$ & $84.1 \%$ & $4.5 \%$ & $11.4 \%$ \\
\hline Severe muscle pain & $83.2 \%$ & $8.0 \%$ & $8.8 \%$ & $67.4 \%$ & $10.5 \%$ & $22.1 \%$ & $63.6 \%$ & $11.4 \%$ & $25.0 \%$ \\
\hline Dark colored urine & $71.7 \%$ & $12.4 \%$ & $15.9 \%$ & $46.5 \%$ & $29.1 \%$ & $24.4 \%$ & $52.3 \%$ & $13.6 \%$ & $34.1 \%$ \\
\hline $\begin{array}{l}\text { Scanty or no urine } \\
\text { output }\end{array}$ & $75.2 \%$ & $9.7 \%$ & $15.0 \%$ & $50.0 \%$ & $23.3 \%$ & $26.7 \%$ & $54.5 \%$ & $11.4 \%$ & $34.1 \%$ \\
\hline Shock/collapse & $93.8 \%$ & $3.5 \%$ & $2.7 \%$ & $87.2 \%$ & $5.8 \%$ & $7.0 \%$ & $84.1 \%$ & & $15.9 \%$ \\
\hline
\end{tabular}

DK- don't know even after being prompted

Table 3 shows the responses of medical/health service providers with regard to their knowledge on type of lab investigations conducted for diagnosis of snake bite. Majority of doctors mentioned about eight type of lab investigations ranging from $47.0 \%$ to $86.7 \%$ followed by nurses ranging from $51.2 \%$ to $88.4 \%$ and other health practitioners mentioned about lab investigations ranging from $43.0 \%$ to $61.4 \%$.

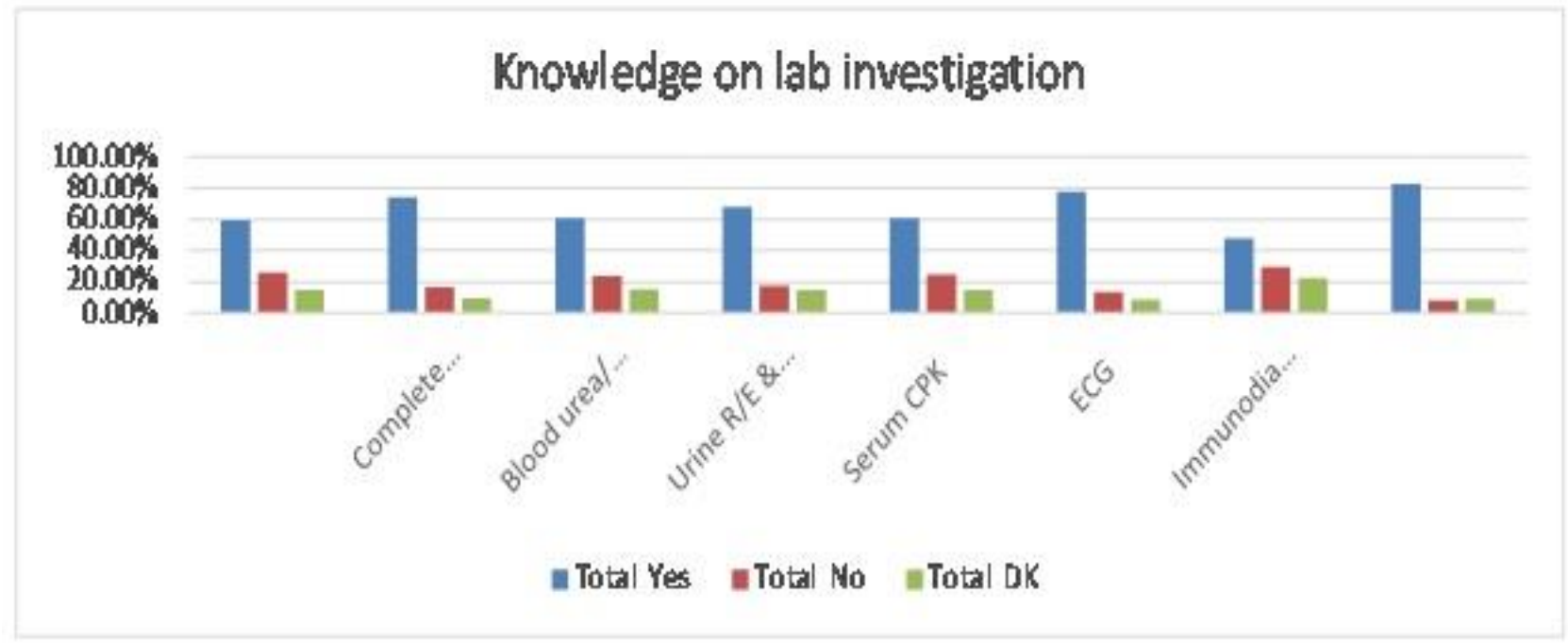

Figure I: Knowledge of Lab Investigations 
In sum, it is observed that almost $8.2 \%$ to $25.9 \%$ health professional are found to have wrong notion about some of the lab investigations followed by $9.1 \%$ to $15.0 \%$ of health professionals did not make any response about some of lab investigations. This is a clear indication that the health professionals as whole are not aware of different lab investigations needed for diagnosis of snake bite. So, it is obvious from findings that need for more adequate information and awareness amongst the medical professionals should be ensured for enhancing their knowledge about lab investigations for proper and prompt diagnosis of snake bite.
Table 4 provides information with regard to knowledge level of health professionals about complication of injecting anti-venom to snake bite victims. The findings show about $61.1 \%$ to $70.8 \%$ of the doctors could mention all the three complications induced due to injecting anti venom to the snake bite victims followed by $38.4 \%$ to $50.0 \%$ of the nurses could mention about complication likely to occur after the injection of anti-venom to the snake bite victims and only $43.2 \%$ of the practitioners could mention about complication of anti-venom injection.

Table 3: Knowledge on type of lab investigation for snake bite by health service providers

\begin{tabular}{|c|c|c|c|c|c|c|c|c|c|}
\hline \multirow{3}{*}{$\begin{array}{l}\text { Knowledge on lab } \\
\text { investigation }\end{array}$} & \multicolumn{9}{|c|}{ Type of health service providers } \\
\hline & \multicolumn{3}{|c|}{ Doctor $(n=113)$} & \multicolumn{3}{|c|}{ Nurse $(n=86)$} & \multicolumn{3}{|c|}{ Others $(n=44)$} \\
\hline & Yes & No & DK & Yes & No & DK & Yes & No & DK \\
\hline $\begin{array}{l}20 \text { minutes whole } \\
\text { blood clotting }\end{array}$ & $61.9 \%$ & $29.2 \%$ & $8.8 \%$ & $62.8 \%$ & $19.8 \%$ & $17.4 \%$ & $45.5 \%$ & $29.5 \%$ & $25.0 \%$ \\
\hline $\begin{array}{l}\text { Complete blood } \\
\text { count }\end{array}$ & $77.9 \%$ & $15.0 \%$ & $7.1 \%$ & $81.4 \%$ & $12.8 \%$ & $5.8 \%$ & $50.0 \%$ & $27.3 \%$ & $22.7 \%$ \\
\hline $\begin{array}{l}\text { Blood urea/ } \\
\text { creatinine \& } \\
\text { electrolyte }\end{array}$ & $64.6 \%$ & $30.1 \%$ & $5.3 \%$ & $66.3 \%$ & $11.6 \%$ & $22.1 \%$ & $40.9 \%$ & $31.8 \%$ & $27.3 \%$ \\
\hline Urine $\mathbf{R} / \mathbf{E}$ & $80.5 \%$ & $15.0 \%$ & $4.4 \%$ & $62.8 \%$ & $17.4 \%$ & $19.8 \%$ & $45.5 \%$ & $22.7 \%$ & $31.8 \%$ \\
\hline Serum CPK & $60.2 \%$ & $35.4 \%$ & $4.4 \%$ & $68.6 \%$ & $11.6 \%$ & $19.8 \%$ & $45.5 \%$ & $22.7 \%$ & $31.8 \%$ \\
\hline ECG & $85.0 \%$ & $11.5 \%$ & $3.5 \%$ & $80.2 \%$ & $14.0 \%$ & $5.8 \%$ & $54.5 \%$ & $18.2 \%$ & $27.3 \%$ \\
\hline Immunodiagnosis & $46.9 \%$ & $38.1 \%$ & $15.0 \%$ & $51.2 \%$ & $22.1 \%$ & $26.7 \%$ & $43.2 \%$ & $22.7 \%$ & $34.1 \%$ \\
\hline $\begin{array}{l}\text { Blood grouping \& } \\
\text { Rh typing }\end{array}$ & $86.7 \%$ & $9.7 \%$ & $3.5 \%$ & $88.4 \%$ & $3.5 \%$ & $8.1 \%$ & $61.4 \%$ & $13.6 \%$ & $25.0 \%$ \\
\hline
\end{tabular}

It is also observed that the health professionals as a whole could mention about $49.8 \%$ to $57.6 \%$ of the complication of anti-venom injection. So this implies that health professionals should be more informed about complication of anti-venom injection so that fatal consequence from venomous snake bite may be effectively reduced and controlled.

\section{Table 4: Knowledge about complication of injecting anti-venom}

\begin{tabular}{|l|l|l|l|l|l|l|l|l|l|l|}
\hline $\begin{array}{l}\text { Knowledge on } \\
\text { complication of } \\
\text { injecting anti- } \\
\text { venom }\end{array}$ & Yes & No & DK & Yes & No & DK & Yes & No & DK \\
\hline $\begin{array}{l}\text { Early anaphylaxis } \\
\text { urticaria, dyspnoea } \\
\text { and hypotension })\end{array}$ & $70.8 \%$ & $8.0 \%$ & $21.2 \%$ & $47.7 \%$ & $4.7 \%$ & $47.7 \%$ & $43.2 \%$ & $4.5 \%$ & $52.3 \%$ \\
\hline $\begin{array}{l}\text { Diarrhoea and } \\
\text { vomiting }\end{array}$ & $61.1 \%$ & $15.0 \%$ & $23.9 \%$ & $38.4 \%$ & $14.0 \%$ & $47.7 \%$ & $43.2 \%$ & $9.1 \%$ & $47.7 \%$ \\
\hline $\begin{array}{l}\text { Pyrogenic } \\
\text { reaction(fever } \\
\text { \&chill) }\end{array}$ & $68.1 \%$ & $2.7 \%$ & $29.2 \%$ & $50.0 \%$ & $2.3 \%$ & $47.7 \%$ & $43.2 \%$ & $4.5 \%$ & $52.3 \%$ \\
\hline
\end{tabular}

\section{Discussion}

Snake bite in Bangladesh is a public health problem. The lack of anti-venom makes the case worsier. There is insufficient knowledge, skill and experience of how to treat snake bite victims. It is recommended that training package (based on the WHO AFRO guidelines/National Guideline) should be given to HPs, including first-aid and preventive measures (for local community education), emphasizing the need for early referral 
and appropriate care, case documentation and reporting and public awareness creation and preserving the dead snake inform aldehyde, labeled with patient's details for later expert identification. A change of attitude on traditional knowledge by training or awareness should be provided to traditional healers and community elders.
Furthermore, the government should take urgent measures to ensure the sustainable availability of appropriate type of anti-venom which is specific to locally know venomous snake in the country. Finally, local production of anti-venom from most dangerous species in the country is recommended and the government should facilitate technology transfer from developed country for local anti-venom production.

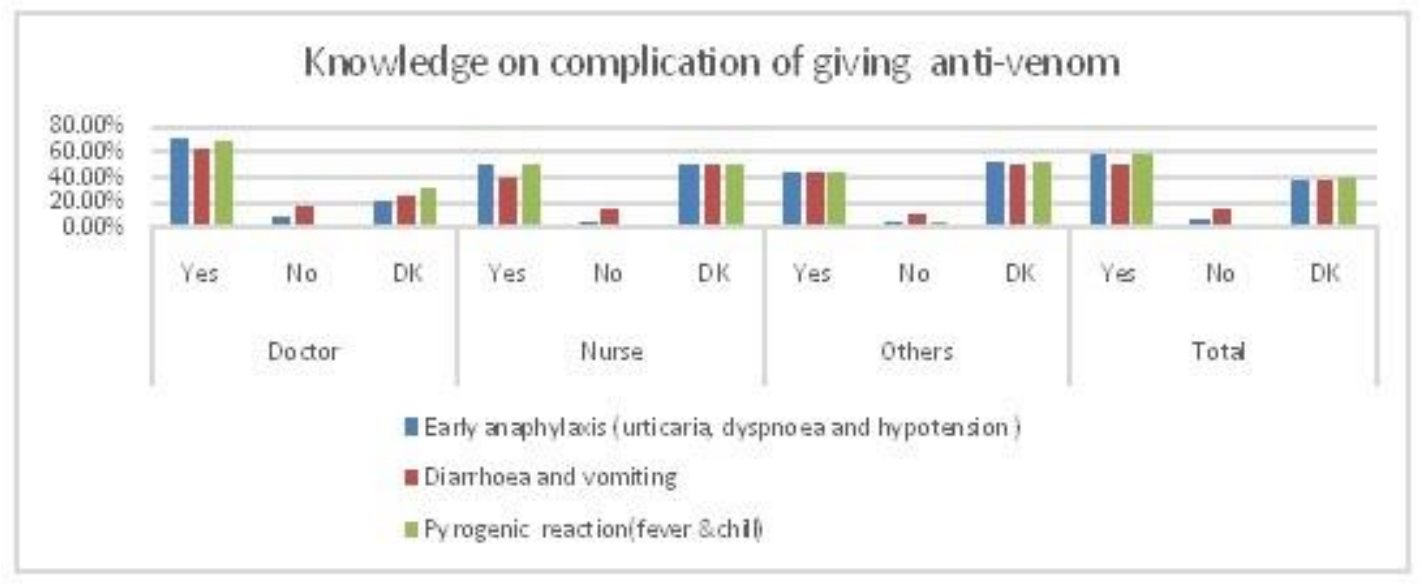

Figure II: Knowledge on Complications of giving Anti-Venom

\section{Conclusion}

There is insufficient knowledge, skill and experience of how to treat snake bite victims. It is recommended that training package (based on the WHO AFRO guidelines) should be given to

\section{References}

1. Alirol E, Sharma SK, Bawaskar HS, Kuch U, Chappuis F. Snake bite in South Asia: a review. PLoS neglected tropical diseases. 2010;4(1):e603

2. Williams D, Gutiérrez JM, Harrison R, Warrell DA, White J, Winkel KD, Gopalakrishnakone P. The Global Snake Bite Initiative: an antidote for snake bite. The lancet. 2010;375(9708):89-91.

3. McKinney PE. Out-of-hospital and interhospital management of crotaline snakebite. Annals of emergency medicine. 2001;37(2):168-74

4. Chen C, Gui L, Kan T, Li S, Qiu C. A survey of snakebite knowledge among field forces in China. International journal of environmental research and public health. 2016;14(1):15

5. Simpson ID. A study of the current knowledge base in treating snake bite amongst doctors in the high-risk countries of India and Pakistan: does snake bite treatment training reflect local requirements? Transactions of the Royal Society of Tropical Medicine and Hygiene. 2008;102(11):1108-14

6. Fung HT, Lam SK, Lam KK, Kam CW, Simpson ID. A survey of snakebite management knowledge amongst select physicians in Hong Kong and the implications for
HPs, including first-aid and preventive measures (for local community education), emphasizing the need for early referral and appropriate care, case documentation and reporting and public awareness creation and preserving the dead snake inform aldehyde, labeled with patient's details for later expert identification. snakebite training. Wilderness \& environmental medicine. 2009;20(4):364-72

7. Rahmatullah M, Ferdausi D, Mollik A, Jahan R, Chowdhury MH, Haque WM. A survey of medicinal plants used by Kavirajes of Chalna area, Khulna district, Bangladesh. African Journal of Traditional, Complementary and Alternative Medicines. 2010;7(2)

8. Ahmed SM, Ahmed M, Nadeem A, Mahajan J, Choudhary A, Pal J. Emergency treatment of a snake bite: Pearls from literature. Journal of Emergencies, Trauma and Shock. 2008;1(2):97.

9. Warrell DA. Snake bite. Lancet. 2010;375(9708):77-88

10. Gutiérrez JM, Theakston RD, Warrell DA. Confronting the neglected problem of snake bite envenoming: the need for a global partnership. PLoS medicine. 2006;3(6):e150.

11. Mohapatra B, Warrell DA, Suraweera W, Bhatia P, Dhingra N, Jotkar RM, Rodriguez PS, Mishra K, Whitaker R, Jha P, Million Death Study Collaborators. Snakebite mortality in India: a nationally representative mortality survey. PLoS neglected tropical diseases. 2011;5(4):e1018 